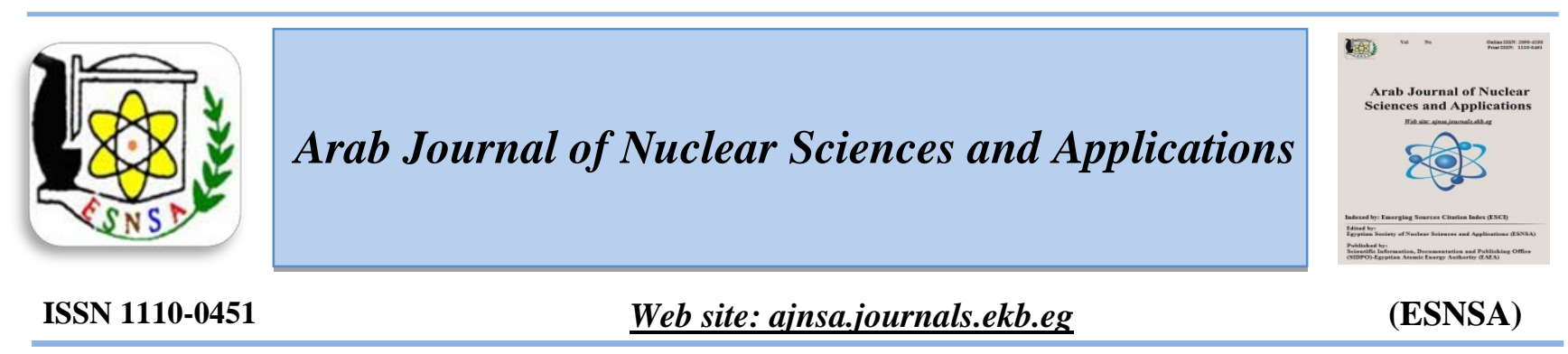

\title{
Improvement of Nitrogen Fertilization Practices for Efficient Use by Wheat Irrigated With Saline Water under Mulching Using ${ }^{15} \mathrm{~N}$ Technique
}

\author{
M.F.Kassab $^{1 *}$, Y. G. M.Galal ${ }^{1}$, A.M. El-Gindy ${ }^{2}$, K. F. El-Bagoury ${ }^{2}$, Sh. K. El-Tohory ${ }^{1}$ \\ (1) Soil and Water Research Department, Nuclear Research Center, Atomic Energy Authority, Cairo, Egypt \\ ${ }^{(2)}$ Agricultural Engineering Department, Faculty of Agriculture, Ain Shams University, Cairo, Egypt
}

Received $12^{\text {nd }}$ Feb 2017 A field experiment was carried out to investigate the effects of saline irrigation water and soil mulching Accepted $3^{\text {rd }}$ Aug 2017 on the growth and yield of cultivated wheat crop. Wheat yield for non-mulched treatment irrigated by fresh water (3366 kg.ha-1) was higher than the mulched one irrigated with fresh water $\left(3227 \mathrm{~kg}^{-1} \mathrm{ha}^{-1}\right)$ and also higher than both mulched and non-mulched treatments irrigated by saline water of 6 and 8 dS. $\mathrm{m}^{-1}$. Under non-mulched condition, the treatment of the irrigated by $6 \mathrm{dS} . \mathrm{m}^{-1}$ recorded a higher production of $2411 \mathrm{~kg} . \mathrm{ha}^{-1}$ than those irrigated by $8 \mathrm{dS} \cdot \mathrm{m}^{-1}\left(2231 \mathrm{~kg}^{-h a^{-1}}\right)$. In the same sequence mulched treatment of the irrigated by $6 \mathrm{dS} \cdot \mathrm{m}^{-1}$ recorded a higher yield $\left(2936 \mathrm{~kg} \mathrm{ha}^{-1}\right)$ than the mulched one irrigated by $8 \mathrm{dS} \cdot \mathrm{m}^{-1}\left(2573 \mathrm{~kg}^{-} \mathrm{ha}^{-1}\right)$. The nitrogen uptake by grain of wheat irrigated by fresh water and non-mulching treatments was much better than that in mulching treatments, but, mulching treatment combined with saline water $\left(6\right.$, and $\left.8 \mathrm{dS} . \mathrm{m}^{-1}\right)$ was much better than non-mulched one. Similar trend was noticed with $\mathbf{N}$ uptake by straw. Proportion and absolute values of Nitrogen derived from fertilizer( Ndff) as well as nitrogen use efficiency (NUE) gained by grains or straw were severely reduced by increasing water salinity level as compared to those irrigated with fresh water. Mulching has a positive effect on combating salinity stress. It seems that, in general, mulching made the plants more able to derive more nitrogen from fertilizer and improved NUE. Nitrogen derived from fertilizer by grains was significantly higher than those of straw. Similar trend was noticed for NUE.

Keywords: Drip irrigation, Mulching, ${ }^{15}$ Nitrogen, Salinity, Urea, Wheat

\section{Introduction}

Water scarcity and high costs of chemical fertilizers became a challenge in sustainable agriculture systems. Looking for unconventional water resources and nutrients are urgently needed. In this regard, evaporation reduction and increasing water use efficiency became important targets in research. Soil mulching is a sensible strategy to reduce water evaporation, accelerate crop development, reduce erosion and assist in weed control, but its efficiency for soil salinity control is not as well documented. The benefits of inorganic (plastic) and organic (grapevine pruning residues) mulching for soil salinity and sodicity control were quantified in a grapevine orchard (cultivars 'Autumn' Royal and 'Crimson') dripirrigated with moderately saline waters. Soil saturation extract electrical conductivity (ECe) values increased in all treatments of both grapevines along the irrigation seasons, but the increases were much lower in the mulched than in the bare soils due to reduced evaporation losses and concomitant decreases in salt evapoconcentration. A previous study concluded that the plastic mulch and, particularly, the organic mulch were more efficient than the bare soil for soil salinity and sodicity control [1]. In the same direction, Yang et al. [2] reported that the surface mulch with different materials has a significant effect on reducing evaporation and decreasing soil

Corresponding Author: eng.Mohamed.kassab@gmail.com

DOI: 10.21608/ajnsa.2018.6515

(C) Scientific Information, Documentation and Publishing Office (SIDPO)-EAEA 
salinity level in addition to its effect on wheat production. As for the effect of mulching on water evaporation, Abouziena et al. [3] reported that the layer of mulch can reduce evaporation by as much as $75 \%$. Soil mulching raises soil water storage (up to $41 \%$ ), raised grain water use efficiency by $14 \%$ and reduce water loss from 0 to $30 \mathrm{~cm}$ soil depth. They showed that plastic mulching leads to save water and benefits crop performance under water stress. Dealing with mulching effect on wheat crop, straw mulch found to conserve more soil water, but decreased wheat grain yield probably due to low temperature. Concrete mulch had a similar effect, as compared with plastic film mulch, on promoting winter wheat development and growth [2-4] and for cotton [5]. Therefore, recent work aimed at evaluation of straw mulching effects on nitrogen status in wheat plants irrigated with saline water of different salinity levels using surface drip irrigation system in sand soil.

\section{Materials and Methods}

\section{Field settings}

Field experiment was conducted in sand soil at the Experimental Farm of Soils and Water Research Department, Nuclear Research Center, Atomic Energy Authority, Cairo, Egypt, $30^{\circ} 24^{`} \mathrm{~N}$ latitude, $31^{\circ} 35^{\circ}$ E longitude, while the altitude is $20 \mathrm{~m}$ above the sea level. Surface soil samples $(0-15 \mathrm{~cm})$ were collected for physical and chemical analyses according to a previous study [6]. The experimental soil was classified as sand soil with $\mathrm{pH}, 7.8$; EC, $0.46 \mathrm{dS} . \mathrm{m}^{-1} ; \mathrm{CaCO}_{3} \%, 1.2 ; \mathrm{OM} \%$, 0.043; available $\mathrm{N}, 0.01$ meq. $100 \mathrm{~g}^{-1}$.

Wheat (Triticum aestivum L.) Masr 2 variety was used as a test crop. Crop coefficient values (Kc) and the active root depth of spring wheat (0.9 to $1.5 \mathrm{~m}$ ) which spreads of $0.15-0.25 \mathrm{~m}$, was obtained from the previously published data [7].

Recommended doses of NPK fertilizers were applied according to the recommendations of the Ministry of Agriculture and Land Reclamation, Egypt. The soil surface was leveled and mineral fertilizers were applied at the rate of $286 \mathrm{~kg} \mathrm{~N}^{-1}$ in the form of urea (fertigation), $71.5 \mathrm{~kg} \mathrm{P}_{2} \mathrm{O}_{5} \mathrm{ha}^{-1}$ $(15 \% \mathrm{P})$ as super phosphate and $57 \mathrm{~kg} \mathrm{~K}_{2} \mathrm{O} \mathrm{ha}^{-1}$ $(48 \% \mathrm{~K})$ as potassium sulfate were thoroughly mixed with soil before cultivation. During nitrogen fertilization, catch cans put down dripper in ${ }^{15} \mathrm{~N}$ micro-plots and after the process completion, ${ }^{15} \mathrm{~N}$ - labelled urea with $4.99 \%{ }^{15} \mathrm{~N}$ atom excess, was applied manually in relevant microplots.

Fresh water $\mathrm{F}\left(0.5 \mathrm{dS} \mathrm{m}^{-1}\right), \mathrm{S}_{1}\left(6 \mathrm{dS} \mathrm{m}^{-1}\right)$ and $\mathrm{S}_{2}(8$ $\mathrm{dS} \mathrm{m}^{-1}$ ) were applied with or without mulching (rice straw) to the soil. The saline irrigation water was artificially prepared by mixing fresh water with natural salt collected from (salt pans) to reach the desired concentrations of 6 and $8 \mathrm{dS} \mathrm{m}{ }^{-1}$.

\section{Plant analysis and measurements}

After harvest, samples of wheat grains and straw were taken (143 day from sowing) and then dried at $70{ }^{\circ} \mathrm{C}$ for 24 hours to determine the dry weight, hence ground and subjected to wet digestion in concentrated $\mathrm{H}_{2} \mathrm{SO}_{4}$ and $\mathrm{H}_{2} \mathrm{O}_{2}$, then kept for analysis according to the method described by Estefan et al. [8]. ${ }^{14} \mathrm{~N} /{ }^{15} \mathrm{~N}$ ratio analysis was carried out using emission spectrometer analyzer model Fischer NOI-6PC following the description reported in a previous study [9]. Distinguishing between the different sources of nitrogen gained by different plant parts, i.e. Ndff, and \%NUE, was carried out using standard equations after IAEA [9].

The experimental treatments were distributed in completely randomized block design, and statistical analysis was carried out according to SAS software program.

\section{Results and Discussion}

Wheat yield

Wheat grain yield under fresh water treatments recorded 3366.5 and $3227.2\left(\mathrm{~kg} . h a^{-1}\right)$ for nonmulching and mulching, respectively. Plants irrigated with $6 \mathrm{dS} \mathrm{m}^{-1}$ salinity level resulted in 2411.6 and $2936.4 \mathrm{~kg} \mathrm{ha}^{-1}$ of grains, while those irrigated with $8 \mathrm{dS} \mathrm{m}^{-1}$ salinity level recorded 2231.9 and $2573.1 \mathrm{~kg} \mathrm{ha}^{-1}$ for non-mulched and mulched treatments, respectively (Fig. 1). These results confirmed the effectiveness of mulching technique on improving wheat yield. Using saline water and rice straw mulch, Zhang et al. [10] showed that the use of mulches significantly reduced ET of Swiss chard and also effectively reduced salt accumulation under a high saline irrigation. In this respect, Mansour et al. [11] demonstrated that wheat (variety Masr 2) grown on sand soil under sprinkler irrigation system with three water consumptive use levels $(100,75$, and $50 \%$ ) from (ETc) have a productivity of 1179.85, 
1342.75 and $1379.30 \mathrm{~kg} \mathrm{ha}^{-1}$. The obtained results of the present work are almost in agreement with those recorded in previous studies [12, 13].

On the basics documented in Irrigation and Drainage Paper No. 29 [14], the expected reductions in the yield due to salinity stress for 6 and $8 \mathrm{dS} \mathrm{m} \mathrm{m}^{-1}$ are 23 and 46\%, respectively. The actual reduction of the wheat yield (\%) due to salinity stress for 6 and $8 \mathrm{dS} \mathrm{m}^{-1}$ are 28 and 34\%, respectively under non-mulching, but the reduction of the wheat yield (\%) due to salinity treatments under mulching for 6 and $8 \mathrm{dS} \cdot \mathrm{m}^{-1}$ were 13 and $24 \%$, respectively.

\section{Nitrogen uptake}

The $\mathrm{N}$ uptake by wheat plant grown on sand soil treated with different water salinity and rice straw mulching is presented in Table (1). Data indicated that, all treatments tended to increase nitrogen uptake under mulching treatments as compared to non-mulching treatments. On the other hand, the highest value of nitrogen uptake by grain was recorded with fresh water without mulching treatment and the lowest value was recorded with saline water $\left(8 \mathrm{dS} \mathrm{m}^{-1}\right)$ without mulching. Finally, under organic mulching strategy, the highest value of total nitrogen uptake by shoots was recorded under mulched soil with the availability of $100 \%$ ETc recommended irrigation under different levels of salinity.

Nitrogen derived from fertilizer (Ndff) and nitrogen use efficiency (NUE)

Nitrogen gained by grains and straw from fertilizer either as percentage or absolute value as affected by mulching and salinity levels is presented in Table (2). Plants irrigated with fresh water, but uncovered with rice straw recorded $51 \%$ and about $47 \%$ of nitrogen uptake which were derived from fertilizer by grains and straw, respectively. It accounts for 78.5 and $21.8 \mathrm{~kg} \mathrm{~N} \mathrm{ha}^{-1}$ for the same sequence. It seems that fresh water irrigated plants and mulched with rice straw achieved more nitrogen derived from fertilizer as compared to the non-mulched one. This holds true with grains and straw-Ndff. On the other hand, irrigation with saline water of $6 \mathrm{dS} \mathrm{m}^{-1}$ induced severe reduction in Ndff by grains or straw when non-mulched soil was considered. Mulched soil under $6 \mathrm{dS} \mathrm{m}^{-1}$ salinity level showed a slight increase in Ndff by either grains or straw compared to the non- mulched soil. A similar trend, but to somewhat lower extent, was noticed with $8 \mathrm{dS} \mathrm{m}^{-1}$ water salinity level.

In conclusion, the proportion and absolute values of Ndff gained by either grains or straw were severely reduced by increasing water salinity level as compared to those irrigated with fresh water. Mulching has a positive effect on combating salinity stress. It seems that, in general, mulching made the plants more able to derive more nitrogen from fertilizer. Nitrogen derived from fertilizer by grains was significantly higher than those of straw.

Considering the efficient use of mineral fertilizer, data indicated that the highest \%NUE was detected with fresh water irrigated plants (Table 2). In this respect, mulching treatment had improved NUE as compared to the non-mulched one. NUE of grains was significantly higher than those recorded with straw. Efficient use of nitrogen fertilizer by either grains or straw was dramatically reduced by irrigation with saline water. A severe reduction in NUE by grains and straw was detected with $8 \mathrm{dS}$ $\mathrm{m}^{-1}$ as compared to $6 \mathrm{dS} \mathrm{m}^{-1}$ salinity level. Generally, mulching treatment achieved an improvement in NUE by grains and shoots. In other turn, mulched plants have the opportunity to combat water salinity stress more effectively than the non-mulched plants. In this regard, Liu et al. [15] stated that mulching treatments markedly promoted maize $\mathrm{N}$ accumulation and especially maintained higher $\mathrm{N}$ uptake rates. At the same time, they suggested that mulching, especially plastic film (FM), is an effective measure for increasing NUE and grain yield. In the same line, Wang et al. [16] found that $\mathrm{N}$ uptake derived from fertilizer (\%Ndff) by plastic mulched maize cropping system averaged 26.8-32.4\% compared with 67.6-73.2 \% derived from soils (\%Ndfs ). Split applications of $\mathrm{N}$ significantly increased the Ndff in plant. These portions are to some extent lower than those we have in the present study. They added that the ${ }^{15} \mathrm{~N}$ recovery efficiency $\left({ }^{15} \mathrm{~N}\right)$ was 37.5 and $39.1 \%$ for treatments N2 (40-60 \%$0)$ and N3 (40-30-30\%), respectively, and was significantly higher than that for $\mathrm{N} 1(100 \%-0-0)$ treatment (27.9\%), this NUE\% was nearly similar to the data reported in the present study, especially under fresh water irrigated plants. 
Regarding salinity effect, Ragab et al. [17] found that increasing water salinity in sandy soil up to $4.85 \mathrm{dS} \mathrm{m}^{-1}$ reduces the grain yield of wheat by 23 $\%$. The yield reduction increases by increasing salinity of irrigation water and reaches its maximum at $8.86 \mathrm{dS} \mathrm{m}^{-1}$ of salinity level. These results are partially in harmony with those obtained in the present study.
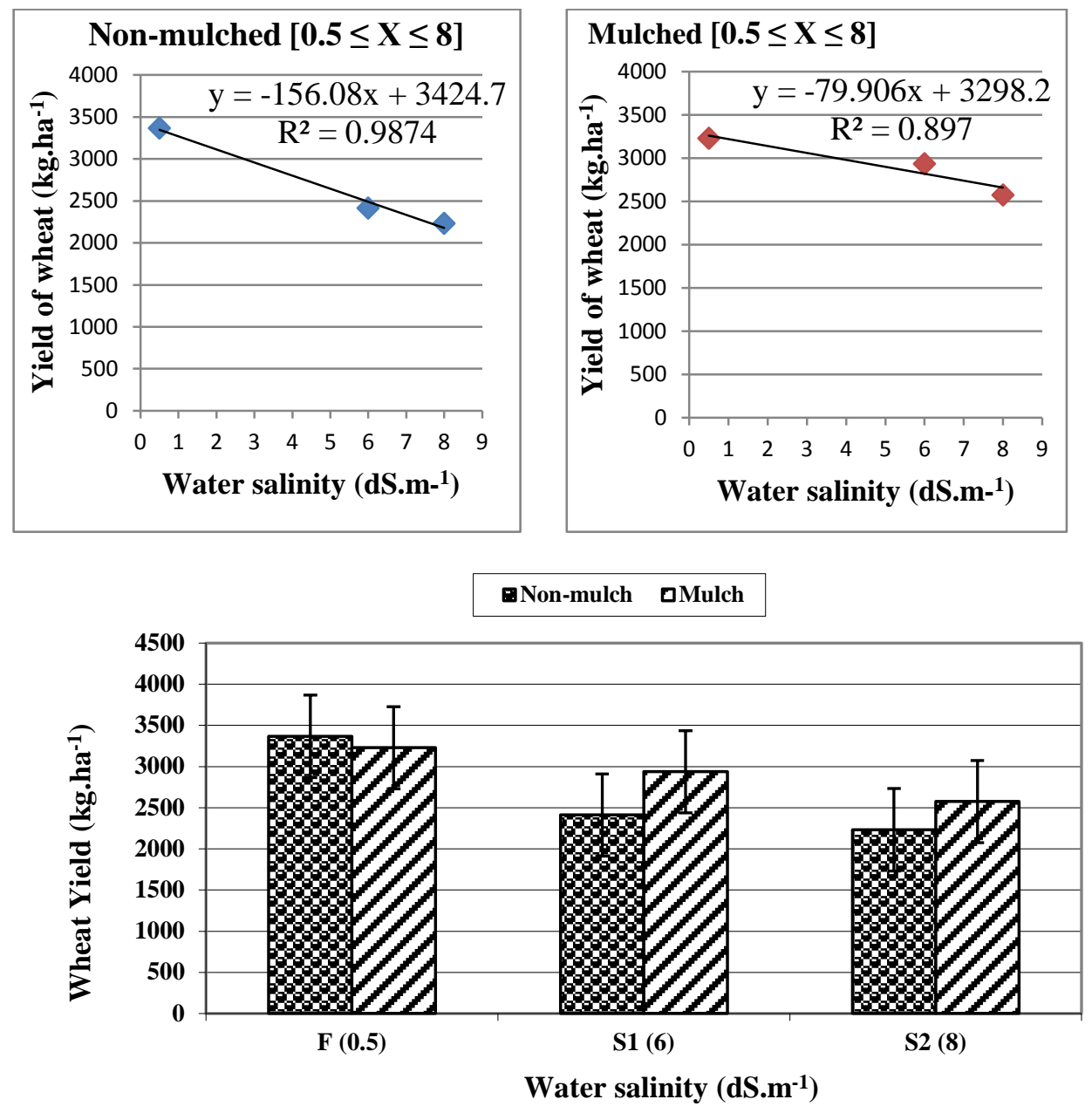

Fig. (1): Effect of mulching and water salinity treatments on wheat yield

Table (1): Nitrogen uptake by grains and straw of wheat crop as affected by water salinity and soil mulching

\begin{tabular}{ccc}
\hline \multirow{2}{*}{ Treatment } & Grains & N uptake kg ha $^{\mathbf{- 1}}$ \\
& 42.6 & Straw \\
\hline FUN & 38.0 & 17.8 \\
FC & 29.5 & 23.2 \\
S1UN & 29.9 & 7.9 \\
S1C & 22.7 & 10.7 \\
S2UN & 28.5 & 7.3 \\
S2C & 9.7 \\
\hline
\end{tabular}

L.S.D 0.05 $=$ FS(FRESH+S1+S2)(0.689), MULCH (n.s), FSm (n.s)

FUN, fresh water uncovered, FC, fresh water covered, $S 1,6 \mathrm{dS} \mathrm{m}^{-1}, \mathrm{~S} 2,8 \mathrm{dS} \mathrm{m}^{-1}$ 
Table (2): Nitrogen derived from fertilizer by grains and straw of wheat crop and NUE as affected by soil mulching and irrigation water salinity

\begin{tabular}{ccccccc}
\hline & \multicolumn{5}{c}{ Nitrogen Derived From Fertilizer NDFF \& \%NUE } \\
Treatment & \multicolumn{3}{c}{ Grains } & & Straw & \\
& \%Ndff & kg ha $^{-1}$ & \%NUE & \%Ndff & kg ha $^{-1}$ & \%NUE \\
\hline Fun & 51.3 & 78.5 & 27.4 & 46.8 & 21.8 & 7.6 \\
FC & 55.8 & 85.0 & 29.7 & 48.3 & 23.7 & 8.3 \\
$\mathrm{~S}_{1}$ un & 42.0 & 45.2 & 15.8 & 35.4 & 10.0 & 3.5 \\
$\mathrm{~S}_{1} \mathrm{C}$ & 45.0 & 57.3 & 20.0 & 39.9 & 16.8 & 5.9 \\
$\mathrm{~S}_{2}$ un & 40.0 & 42.3 & 14.8 & 30.2 & 7.7 & 2.7 \\
$\mathrm{~S}_{2} \mathrm{C}$ & 41.0 & 47.3 & 16.5 & 33.4 & 11.5 & 4.0 \\
\hline
\end{tabular}

\section{References}

1- Aragüés, R. and E. Teresa. Spanish Journal of Agricultural Research. 12(2): 501-508 (2014).

2- Yang, Y. M; L. Xiao-jing; L. Wei-qiang and L. Cun-zhen. J Zhejiang Univ Science B. 7(11):858867 (2006).

3- Abouziena, H. F.; H. M. El-Saeid and A. A. E. Amin. International Journal of Chem. Tech. Research. 7(1): 323-336 (2015).

4- Bezborodova, G. A.; D. K. Shadmanovb; R. T. Mirhashimovb; T. Yuldashevc; A. S. Qureshid; A. D. Noblee and M. Qadir. Agriculture, Ecosystems and Environment. 138:95-102 (2010).

5- Han, M.; C. Zhao; G. Feng; Y. Yan and Y. Sheng. Water 7: 2622-2640 (2015).

6- Carter, M.R. and Gregorich, E.G. Soil Sampling and Methods of Analysis. 2 nd ed. CRC, Boca Raton, FL. 1224 pp (2008).

7- FAO. Yield response to water. FAO Irrigation and Drainage. Paper No. 33. Rome (1986).

8- Estefan, G.; R. Sommer and J. Ryan. Methods of soil, plant and water analysis: A manual for the West Asia and North Africa regions. International Center for Agricultural Research in the Dry Areas (ICARDA), 3rd Ed (2013).

9- IAEA, Vienna. Use of isotope and radiation methods in soil and water management and crop nutrition. Manual Training Course Series No.14. IAEA, Vienna (2001).
10- Zhang, Q. T.; M. Inoue; K. Inosako; M. Irshad; K. Kondo; G. Y. Qiu and S. P. Wang. Journal of Food, Agriculture \& Environment. 6(3\&4):480-485 (2008).

11- Mansour, H. A.; M. E. El-Hagarey; A. Saad; A. A. A. Ibrahim and V. F. Bralts. European Journal of Academic Essays. 2 (6):1-6 (2015).

12- Mojid, M. A.; K. F. I. Murad; S. S. Tabriz and G. C. L. Wyseure. J. Bangladesh Agril. Univ. 11(1): 141-146 (2013).

13- Abdel Monem, M. A. S. Nitrogen uptake efficiency of irrigated wheat in Egypt .optimization nitrogen fertilizer application of irrigated wheat, co-ordinate project organized by FAO and IAEA, Printed by IAEA2000, Austria (2000).

14- Ayers, R. S. and D. W. Westcot. Water Quality for Agriculture, FAO Irrigation and Drainage Paper 29 rev 1. FAO, UN, Rome (1985).

15- Liu, J.; Sh. Luo; Sh. Li; A. Zhan; L. Bu; H. Chen and X. Chen. Nutr Cycl Agroecosyst, 101: 271-283 (2015).

16- Wang, S.; S. Luo; S. Yue; Y. Shen and S. Li. Nutr Cycl Agroecosyst. 105: 129-140 (2016).

17- Ragab A. A. M. M.; F. A. Hellal and M. Abd ElHady. Irrigation water salinity effects on some soil water constants and plant. In: Twelfth International Water Technology Conference Proceedings, IWTC12 2008 Alexandria, Egypt. 1-14 (2008). 